be widespread I now accept the majority view that there should be a second person present to give the anaesthetic; but this would bring no gain in safety unless that person fully understood and kept constantly in mind the peculiar danger of anaesthesia in the dental chair. Whether this person needs to be qualified in medicine or dentistry is open to question. I think not and have suggested ${ }^{6} 7$ the establishment of an alternative grade.-I am, etc.,

Salisbury, Wilts

J. G. BOURNE

1 Bourne, J. G., British Medical fournal, 1967, 3, 616.

2 Bourne, J. G., Lancet, 1966, $1,879$.

3 Bourne, J. G., Anaesthesia, 1970, 25, 473.

Bourne, J. G., Lancet, 1973, 1, 35.

Ministry of Health, Dental Anaesthesia, Report of

a foint Subcommittee of the Standing Medical and Dental Advisory Committee. London,

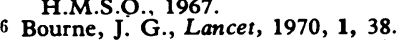

6 Bourne, J. G., Lancet, 1970, 1, 38.
7 Bourne, J. G., Lancet, 1970, 2, 1311.

\section{Depression and Organic Disorder}

SIR,-On my return from abroad I have read the correspondence from Dr. G. Dodds (22 September, p. 638) and from Dr. Irene P. Rowlands and my colleague Mr. A. N. Smith (27 October, p. 234).

Dr. Rowlands interprets me correctly when she writes that I "merely intended that one must not lose sight of depression as the 'writing on the wall' in carcinoma occurring in later life." It was indeed an off-the-cuff remark in closing the meeting as I noted that this feature had not arisen in the discussion at the clinicopathological conference. Nevertheless, Dr. Dodd's remarks on the many other reasons why such a patient might well develop depression are perfectly pertinent and Mr. Smith has answered appropriately the question that he raised relating to the absence of this factor in the retrospective survey. In the event, my closing remark has had the advantage of greater publicity than it would have achieved if I had surrounded it with provisos.

I am unsure what Dr. Rowlands meant by my "usual flair for diagnostic slogans," but as the tone of the letter is clearly friendly I shall take the liberty of assuming that flair compensates for slogans.-I am, etc.,

Gastro-Intestinal Unit, Western General Hospital, Edinburgh

\section{Effect of Beta-receptor Stimulation on the} Platelet Count

SIR,-The intravenous infusion of adrenaline causes an instant release of platelets from the exchangeable splenic platelet pool (E.S.P.P.), resulting in a simultaneous increase in the peripheral platelet count. ${ }^{1-4}$ The mechanism behind this effect of adrenaline on the E.S.P.P. is, however, unclear. In view of the fact that adrenaline stimulates the alpha- as well as the beta-receptors it was considered of interest to study the possible effect of more selective stimulants on the peripheral platelet count. Therefore five healthy male volunteers aged 24-39 (mean 30) years were studied during an intravenous infusion of isoprenaline lasting 20 minutes $(0.015 \mu \mathrm{g} / \mathrm{kg}$ body weight $/ \mathrm{min})$ on two occasions. Ten minutes before the second infusion the subjects received $10 \mathrm{mg}$ of propranolol intravenously at a constant rate over a 10-minute period. For determination of th: platelet count venous blood was collected at five-minute intervals throughout the $\mathrm{ex}_{2}$ )eriment. The last sample was drawn 20 minutes after the withdrawal of isoprenaline. The counting of platelets was carried out with a Coulter counter Model F, as described elsewhere, ${ }^{5}$ and the absence of platelet aggregates in the blood samples was confirmed by phase microscopy.

During the first experiment a progressive fall in the platelet concentration was observed in all subjects. After 15 minutes of isoprenaline infusion the mean platelet count had decreased to $82 \%$ of the baseline value. After the withdrawal of isoprenaline the platelet count referred to the baseline within 20 minutes. During the second study, when the subjects were pretreated with propranolol, there was no significant change in the peripheral platelet concentration in response to isoprenaline administration.

Thus while adrenaline causes an increase in the peripheral platelet count, there is a decrease in the peripheral platelet concentration in response to isoprenaline. This latter effect of isoprenaline can effectively be blocked if the subject is pretreated with propranolol, a beta-blocking agent. Since it is known that adrenaline exerts its effect on the peripheral platelet count by decreasing the E.S.P.P.1-4 it may well be that isoprenaline exerts an opposite effect on the spleen. These effects might well be mediated by alphaand beta-receptors.-We are, etc.,

JACK KUTTI

SOODABEH SAFAI-KUTTI ULF SMITH

Department of Medicine,

Sahlgren's Hospital

Goteborg, Sweden

Aster, R. H., Fournal of Clinical Investigation, $1966,45,645$.

otilainen, M., Scandinavian fournal of Haematology, 1969, suppl. 5

年, Studies on Platelet Kinetics in Polycythaemia Vera, p.

4 Branehög, I., Weinfeld, A., and Roos, B., British Fournal of Haematology, 1973, 25, 239.

Kutti, J., and Weinfeld, A., Scandinavian fournal of Haematology, 1971, 8, 336.

\section{Anaemia in the Elderly}

SIR,-Dr. J. H. Thomas (3 November, p. 288) reviewed the causes, types, and treatment of anaemia in the elderly and pointed out that a deficient vitamin $\mathrm{C}$ intake is associated with a normocytic and sometimes a macrocytic anaemia. Concomitant with the iron deficiency anaemia commonly found in the elderly, a deficiency of vitamin $C$ is often encountered. ${ }^{2}$ The metabolism of iron is closely related to that of vitamin $\mathrm{C}^{3}$ Iron absorption is enhanced in the presence of vitamin $C,{ }^{4}$ and its mobilization from transferrin to ferritin in the liver and vice versa is dependent on an adequate supply of ascorbic acid. ${ }^{6}$ Optimal haemopoiesis is possible only in the presence of iron and the maturation factors, vitamin $\mathbf{B}_{12}$, folic acid, pyridoxine, and also ascorbic acid, in the bone marrow. In the presence of an adequate supply of the maturation factors, but with a deficiency of vitamin C, optimal haemopoiesis does not take place during adolescence ${ }^{2}$ or in the elderly. ${ }^{28}$ Adequate supplementa- tion in a ra:io of five parts of vitamin $\mathrm{C}$ to one of iron has been shown to enhance haemopoiesis in the elderly in the absence of deficiency of the other factors. ${ }^{389}$

Dr. Thomas suggested a daily intake of an adequa:e amount of protein, $10-12 \mathrm{mg}$ of iron, $2-4 \mu \mathrm{g} B_{1:}, 100 \mu \mathrm{g}$ folic acid, $2 \mathrm{mg}$ pyridoxine, and $35 \mathrm{mg}$ vitamin $\mathrm{C}$, to ensure an adequate supply of these haemopoietic factors for the daily needs of elderly people. Though a daily intake of more than $10 \mathrm{mg}$ of vitamin $\mathrm{C}$ is adequate to prevent scurvy, ${ }^{10}$ $35 \mathrm{mg}$ is not an adequate daily intake to

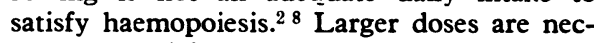
essary to satisfy other metabolic demands of a physiological $^{11}$ or of a pathophysiological nature. ${ }^{12-14}$-We are, etc.,

H. S. $\mathrm{LOH}$ C. W. M. WILSON

Department of Pharmacology,

University of Dublin,

Trinity College,

Taylor, G. F., British Medical fournal, 1973, 1.292.

, H. S., and Wilson, C. W. M., International fournal for Vitamin and Nutration Research,

Loh, H. S., and Wilson, C. W. M., Lancet, 1971, 2, 768

4 Conrad, M. E., and Schade, S. G., Gastroenterology, 1968, 55, 35 .

Mazur, A., Annals of the New York Academy of Sciences, 1961, 92, 223.

6 Cox, E. V., in Vitamins and Hormones, ed. R. S. Harris, I. G. Wool, and J. A. Loraine, vol. 26, Loh, H. S., and Wilson, C. W. M., International fournal for Vitamin and Nutrition Research, $1971,41.445$.

8 Wilson, C. M. W., and Loh., H. S., Nutrition Reports International, 1971, 4, 371

Lee, P. C., Ledwich, J. R., and Smith, D. C., Canadian Medical Association fournal, 1967, Goudsmith, G. A., Annals of the New York Academy of Sciences, 1961,92, 230.

Wilson, C. W. M., and Loh, H. S., Lancet, 1973, 2. 859 .

2 Wilson, C. W. M., and Loh, H. S., Lancet, 1973,

13 Wilson, C. W. M., Loh, H. S., and Foster, F. G., European fournal of Clinical Pharmacology, 1973, 6. 26. ${ }^{\circ}$. Loh, H. S and Foster, F. G., European fournal of Clinical Pharmacology,
1973, 6, 196.

\section{E.S.R. versus Plasma Viscosity Readings} in the Old

SIR,-Following Dr. F. I. Caird's comprehensive account of laboratory findings in the old (10 November, p. 348) I would like to draw attention to some work relating raised erythrocyte sedimentation rate (E.S.R.) with normal or low plasma viscosity to either abnormally low packed cell volume or reduced plasma albumin level. ${ }^{1}$ Albumin disperses rouleaux formation and therefore tends to reduce the E.S.R. whereas globulin enhances rouleaux formation, tending to accelerate the E.S.R. Harris ${ }^{1}$ found that in some old people plasma albumin levels may be reduced in association with malnutrition or malabsorption in the absence of ana ${ }^{\circ} \mathrm{mia}$.

In our hospital group we have used plasma viscosity estimations in place of E.S.R.s for over eight years, the effects due to low packed cell volume or to changes in the red cell surface thus being eliminated. ${ }^{2}$ Low plasma viscosity readings suggest hypoproteinaemia, normal readings virtually exclude inflammatory response from whatever cause, and readings raised above normal require investigation. The test has the advantage of being cheap (virtually the cost of the apparatus), it is rapid (20 seconds per test) reproducible (coefficient of variation $<1 \%$ ), and suitable for postal samples (unlike the 